\title{
Perception and translation of advertising meanings: students ' attitudes
}

\author{
Ekaterina Belousova ${ }^{1 *}$, Lazar Stosic ${ }^{2}$ \\ 1 Don State Technical University, Faculty of Psychology, Pedagogy and Defectology, \\ 344000 Rostov-on-Don, Russia \\ ${ }^{2}$ Association for the Development of Science, Engineering and Education, Belgrade, Serbia
}

\begin{abstract}
The aim of the study presented in the article is an empirical study of semantic attitudes and life meanings of students in the perception of advertising posters. Advertising influence is considered as a process of translation of meanings concentrated in advertising posters. The study sample consisted of 60 students from two universities (Rostov-on-don, Russia). To determine the expression of vital meanings we used the technique of life values Kotlyakov, V. Y. (Y. V. Kotlyakov, 2003), to studies of advertising posters we applied the method of expert evaluations. The results were processed by methods of mathematical statistics: descriptive statistics; nonparametric Kruskal-Wallis H-test for comparison of several independent samples, Spearman rank correlation coefficient. It was shown that in the process of translation of meanings in advertising posters there is an actualization of semantic installations of students. In a sample of students we recorded a tendency to evaluate advertising posters in accordance with the dominant meanings of life. It is shown that there is a relationship between the dominant life meanings of students and their estimates of advertising posters.
\end{abstract}

\section{Introduction}

Questions of advertising perception and attitude to it are traditionally significant for psychology. From social and scientific point of view, the study of these problems is important due to the fact that advertising today is an important part of social life, it is filling more and more areas of social life, playing an important role in the formation of social, psychological and behavioral stereotypes of society as a whole and individual social groups. Advertising surrounds us in any social space and it is a guide to the world of goods and services.

On the one hand, advertising forms the motivational-need sphere of a person and in his mind influences the formation of certain values and ideas related to the consumption of products or services. There are various models of the influence of advertising on consumers, including young people: R. Batra, M. L Ray [1], Izian Idris, Mohd Shukri Ab Yajid and Ali Khatibi [2], W. J. McGuire [1], W. Wells, J. Burnett, S. Moriarty [4]), which showed that in the process of perception of advertising, the impact on the motivational and

\footnotetext{
* Corresponding author: Katy-belousova@mail.ru
} 
value-semantic spheres of personality is carried out through the translation of actual meanings of different nature, aimed at preserving and rooting of stereotypes of advertising messages in the consciousness. This problem is of particular relevance in relation to the student audience, because at this age value and semantic attitudes of personality, patterns and models of social behavior are formed. One of the psychological mechanisms that affect the perception of advertising, comprehension and translation of meanings are different types of installations exists in the works of domestic and foreign scientists (A. G. Asmolov [5], sh. A. Nadirashvili [5], G. Allport [6], D. N. Uznadze [5], V. A. Yadov [6]).

On the other hand, advertisers promote the advertised product by appealing to the existing value-semantic constructs associated with personal attitudes. Advertisers appeal to meanings, translating them into buying motivation. In other words, if one group of consumers buys a product for the purpose of obtaining pleasure, the other - in order to obtain public approval and recognition, to confirm their social status.

Thus the regulating influence of meanings of objects and the phenomena of the reality broadcast in advertizing texts, slogans, perceiving images and influence the course of activity of the subject is not necessarily connected with any form of their presentation in consciousness. It is well known that a large part of the regulatory effects of this kind is transmitted directly to the executive mechanisms of activity, bypassing consciousness, and it is carried out involuntarily and, as a rule, unconsciously.

Thus, there is a need to talk about the translation of meanings in advertising messages and images, serving as conductors of the corresponding effects, actualizing the readiness of the subject to their implementation. Problems of translation of meanings, stylopidae, transfer of meanings in General psychological terms were observed in works of I. V. Abakumova, L. C. Kagermazova, P. N. Ermakov [7], A. K. Belousova [8], D. A. Leontiev [6], E. A. Kuroedova [9]. The widespread understanding of the translation of meanings emphasizes the fact of the transfer of meanings from one subject to another through channels of communication. And since the channels of communication have become verbal and nonverbal, the questions about the translation of meanings through images, images of objects, phenomena, events have been arising.

As one of the mechanisms, updating of broadcast meanings are semantic installation. A. G. Asmolov defined semantic installation as "a form of expression of personal sense in the form of readiness for doing in a certain way of the directed activity" [5]. By definition, D. $\mathrm{N}$. "Semantic installation is a component of executive mechanisms of activity reflecting in itself vital sense of objects and the phenomena of reality at which this activity is directed, and phenomenologically appearing in various forms of influence on course of actual activity" [6].

It is known that the psychological impact of advertising is described by one of the common formulas of AIDA (Atention, Interest, Desire, Activity) [10], according to this in order to attract the attention of consumers it is necessary to focus on the psychological characteristics of the psyche, personality and consciousness. Even in Gestalt psychology, it was emphasized that among other characteristics of perception it is necessary to focus on past experience, apperception, which involves taking into account the value, semantic characteristics of consciousness and personality of a person, the characteristics of his unconscious processes, among which attitudes play the leading role [10]. From the point of view of V. Packard, advertising should focus on the components of the unconscious sphere of man, translating the unconscious into the sphere of consciousness [11]. D trout noted that it is necessary to use the existing human ideas and connections in order to manipulate them for advertising purposes [12].

For consumers, the advertised goods are presented in the form of images of objects or phenomena, and therefore visual images play a key role in advertising products, starting with the appearance of visual advertising in the form of pictures, photographs, images on 
posters and billboards [11]. In the framework of neurolinguistic programming D. grinder talks about psychological methods in advertising, effective at the unconscious level: subtext (second meaning), synesthesia (mixing or switching channels of information), the use of humor. They are also adjacent to the following techniques: marking, speech presuppositions, the creation of complex equivalents, metaphors, adjustment of values, submodalities and others [13]. Particular relevance is the method which means adjustment of values, which includes the orientation of advertising on the basic values of the audience.

\section{Materials and Methods}

The following methods and methodological procedures were used to implement how respondents with different features of the semantic sphere evaluate advertising posters with different semantic orientation.

Participants. The sample consisted of 60 people, who are students in Rostov-on-don (Russia) aged 18 to 24 years: They study in Academy of psychology and pedagogy of the southern Federal University; faculty of Economics and faculty of automation, mechatronics and management of the Don state technical University. The study involved 32 women and 28 men. The choice of the audience was determined by the fact that in the work of O. S. Posypanova [14] this age period is defined as the stage of development of consumer preferences, on which the psychological features of the perception of advertising are laid.

Measures. To study the features of the semantic sphere of students, the V. Yu. Kotlyakov's method of studying the system of life meanings was used [15]. As an object of analysis, advertising posters were selected, appealing to different life meanings: communicative, altruistic, status, cognitive, family, hedonistic, existential, self-realization; a questionnaire was compiled. In the classification focus of the advertising posters we focused on V. Y. Kotlyakov's methodology for the study of the system of life meanings, V. Y. [15]. To establish the correctness of the attribution of advertising posters to a particular meaning, the method of expert assessments was used. Experts were the specialists in the field of psychology, marketing and art in the amount of 5 people. Experts evaluated the advertising posters presented to them and determined the type of orientation of the poster. Thus, the number of most elected points determined the direction of advertising posters. A questionnaire was developed. It was aimed at analyzing the features of students ' perception of the following parameters of posters: advertising image, color scheme, creativity, aesthetics, advertising idea, slogan, compliance with modern demands, competitiveness. These parameters were chosen in accordance with the formal dynamic and informative characteristics that A. N. Lebedev and O. V. Gordekovo proposed [16]. Students were presented with advertising posters, after viewing which they answered the questionnaire. The preferred advertising posters were determined by summing up the students ' grades for each poster.

Data analysis. Primary data of the study were processed by means of mathematical statistics procedures: descriptive statistics; nonparametric Kruskal-Wallis H-test for comparison of several independent samples, Spearman rank correlation coefficient. Standard computer programs for statistical data analysis were used for data processing: SPSS 17.0 for Windows.

\section{Results}

In this study, we have set to ourselves the goal to compare how the transmission of meanings presented in advertising posters to students with different life meanings and semantic settings. 
At the first stage of processing the results of our study in accordance with the data on the methodology of V. Yu.Kotlyakov, students were divided into seven groups according to the degree of expression of their life meaning: "Family", "Self-Realization", "Hedonistic", "Altruistic", "Existential", "Status", "Communicative". "Cognitive" meanings were not allocated to a separate group due to insufficient frequency distribution. To confirm or refute the hypothesis of qualitative differences in the perception of advertising by students with different life meanings, we conducted a statistical analysis using the nonparametric Kruskal-Wallis test to compare several independent samples. After that, we compared the perception of student groups of the proposed advertising posters, analyzing the students' results in answering to questions (Table 1).

Table 1. The average values for evaluating advertising posters by respondents with different meanings

\begin{tabular}{|c|c|c|c|c|c|c|c|c|}
\hline $\begin{array}{l}\text { Advertising } \\
\text { Life } \\
\text { meanings }\end{array}$ & 己 & 号 & $\stackrel{\mathscr{E}}{\stackrel{\tilde{J}}{\omega}}$ & ن & 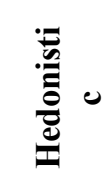 & 䔍 & 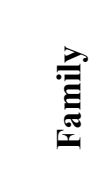 & 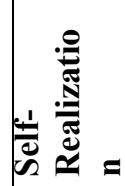 \\
\hline I. Family & $\begin{array}{l}34,82 \\
1\end{array}$ & $\begin{array}{l}40,42 \\
9\end{array}$ & $\begin{array}{l}38,25 \\
0\end{array}$ & $\begin{array}{l}48,78 \\
6\end{array}$ & $\begin{array}{l}42,53 \\
6\end{array}$ & $\begin{array}{l}35,10 \\
7\end{array}$ & $\begin{array}{l}43,64 \\
3\end{array}$ & $\begin{array}{l}49,17 \\
9\end{array}$ \\
\hline $\begin{array}{l}\text { II. Self- } \\
\text { Realization }\end{array}$ & $\begin{array}{l}27,41 \\
2\end{array}$ & $\begin{array}{l}35,47 \\
1\end{array}$ & $\begin{array}{l}34,17 \\
7\end{array}$ & $\begin{array}{l}42,17 \\
7\end{array}$ & $\begin{array}{l}38,88 \\
2\end{array}$ & $\begin{array}{l}27,94 \\
1\end{array}$ & $\begin{array}{l}35,41 \\
2\end{array}$ & $\begin{array}{l}45,76 \\
5\end{array}$ \\
\hline $\begin{array}{l}\text { III. } \\
\text { Hedonistic }\end{array}$ & $\begin{array}{l}34,80 \\
0\end{array}$ & $\begin{array}{l}39,10 \\
0\end{array}$ & $\begin{array}{l}39,10 \\
0\end{array}$ & $\begin{array}{l}41,90 \\
0\end{array}$ & $\begin{array}{l}42,50 \\
0\end{array}$ & $\begin{array}{l}34,30 \\
0\end{array}$ & $\begin{array}{l}40,90 \\
0\end{array}$ & $\begin{array}{l}46,20 \\
0\end{array}$ \\
\hline $\begin{array}{l}\text { IV. } \\
\text { Altruistic }\end{array}$ & $\begin{array}{l}29,88 \\
9\end{array}$ & $\begin{array}{l}37,66 \\
7\end{array}$ & $\begin{array}{l}31,88 \\
9\end{array}$ & $\begin{array}{l}44,55 \\
6\end{array}$ & $\begin{array}{l}37,22 \\
2\end{array}$ & $\begin{array}{l}30,00 \\
0\end{array}$ & $\begin{array}{l}41,77 \\
8\end{array}$ & $\begin{array}{l}47,66 \\
7\end{array}$ \\
\hline $\begin{array}{l}\text { V. } \\
\text { Existential }\end{array}$ & $\begin{array}{l}37,88 \\
9\end{array}$ & $\begin{array}{l}39,88 \\
9\end{array}$ & $\begin{array}{l}38,33 \\
3\end{array}$ & $\begin{array}{l}48,55 \\
6\end{array}$ & $\begin{array}{l}43,66 \\
7\end{array}$ & $\begin{array}{l}38,22 \\
2\end{array}$ & $\begin{array}{l}47,00 \\
0\end{array}$ & $\begin{array}{l}50,2 \\
22\end{array}$ \\
\hline VI. Status & $\begin{array}{l}26,85 \\
7\end{array}$ & $\begin{array}{l}34,85 \\
7\end{array}$ & $\begin{array}{l}39,28 \\
6\end{array}$ & $\begin{array}{l}42,57 \\
1\end{array}$ & $\begin{array}{l}39,57 \\
1\end{array}$ & $\begin{array}{l}25,85 \\
7\end{array}$ & $\begin{array}{l}37,57 \\
1\end{array}$ & $\begin{array}{l}42,57 \\
1\end{array}$ \\
\hline $\begin{array}{l}\text { VII. } \\
\text { Communic } \\
\text { ative }\end{array}$ & $\begin{array}{l}39,00 \\
0\end{array}$ & $\begin{array}{l}44,60 \\
0\end{array}$ & $\begin{array}{l}38,40 \\
0\end{array}$ & $\begin{array}{l}44,00 \\
0\end{array}$ & $\begin{array}{l}43,80 \\
0\end{array}$ & $\begin{array}{l}33,60 \\
0\end{array}$ & $\begin{array}{l}37,00 \\
0\end{array}$ & $\begin{array}{l}52,60 \\
0\end{array}$ \\
\hline $\begin{array}{l}\text { Kruskal- } \\
\text { Wallis H- } \\
\text { test }\end{array}$ & $\begin{array}{l}17,11 \\
5\end{array}$ & $\begin{array}{l}5,15 \\
1\end{array}$ & $\begin{array}{l}8,77 \\
8\end{array}$ & $\begin{array}{l}11,6 \\
64\end{array}$ & $\begin{array}{l}5,91 \\
3\end{array}$ & $\begin{array}{l}9,31 \\
5\end{array}$ & $\begin{array}{l}15,24 \\
8\end{array}$ & $\begin{array}{l}6,91 \\
8\end{array}$ \\
\hline $\mathbf{P}$ &, 009 & ,525 &, 186 &, 070 & ,433 & ,157 &, 018 & ,329 \\
\hline
\end{tabular}

Analysis of tabular data allows you to highlight specific ratings of the preference of the advertising posters that are specific to students selected semantic groups.

So, for the group "family meanings" rating as follows: dominated by posters of "selfrealization", then "Cognitive" and third place goes to "Family"; group "sense of Fulfillment" ranks first poster of the "self-realization", then "Cognitive" and third place goes to "Hedonistic"; for the group of "Hedonistic meaning" first place poster "selfrealization", then "Hedonistic" and third place goes to "Cognitive»; for a group of 
"Altruistic meaning" first place poster "self-realization", then "Cognitive" and third place goes to "Family"; for the group "Existential meanings" the first place is the poster "selfrealization", then "Cognitive" and third place goes to "Family"; group "Status meaning" first place is divided between the poster of "self-realization" and "Cognitive" and the second is "Status"; group "Communicative meaning" first place poster "self-realization", then "Altruistic" and third place goes to "Cognitive".

According to the results of statistical analysis, there are significant differences in the evaluation of " Communicative "( $\mathrm{H}=17,115 ; \mathrm{p}=, 009)$ and" Family " $(\mathrm{H}=15,248 ; \mathrm{p}=, 018)$ advertising posters by students belonging to different value groups.

The next stage of our analysis was the correlation analysis of the relationship between the features of students ' life meanings and their evaluation of advertising posters. Table 2 shows the relationship between the scales of V. Yu. Kotlyakov's "life meanings" methodology and respondents ' evaluation of advertising posters.

Table 2. The relationship between the scales of the methodology "Life meanings" and students ' evaluation of advertising posters

\begin{tabular}{|c|c|c|c|c|c|c|c|}
\hline \multicolumn{2}{|c|}{ Life meanings posters } & ن & 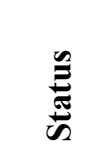 & نٍ.: & 参 & 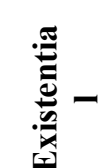 & 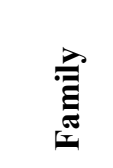 \\
\hline \multirow[t]{2}{*}{$\begin{array}{l}\text { Existenti } \\
\text { al }\end{array}$} & $\begin{array}{l}\text { Spear } \\
\text { man r- } \\
\text { test }\end{array}$ &,- 206 & ,114 &,- 040 &,- 117 &,$- 288^{*}$ &,- 212 \\
\hline & $\mathrm{P}$ & ,114 & ,386 &, 764 &, 373 &, 026 &, 104 \\
\hline \multirow[t]{2}{*}{$\begin{array}{l}\text { Hedonisti } \\
\text { c }\end{array}$} & $\begin{array}{l}\text { Spear } \\
\text { man r- } \\
\text { test }\end{array}$ &,- 026 &, $300^{*}$ & ,311* &,- 006 & ,103 &, $331 * *$ \\
\hline & $\mathrm{P}$ &, 845 &, 020 &, 016 & ,966 &, 433 &, 010 \\
\hline \multirow[t]{2}{*}{$\begin{array}{l}\text { Self- } \\
\text { Realizati } \\
\text { on }\end{array}$} & $\begin{array}{l}\text { Spear } \\
\text { man r- } \\
\text { test }\end{array}$ &, $378 * *$ & ,196 & ,168 &, $255^{*}$ &, $382 * *$ &, $450 * *$ \\
\hline & $\mathrm{P}$ &, 003 &, 133 & ,201 &, 049 &, 003 &, 000 \\
\hline \multirow[t]{2}{*}{ Status } & $\begin{array}{l}\text { Spear } \\
\text { man r- } \\
\text { test }\end{array}$ &,- 092 &,$- 260^{*}$ &,- 092 &,- 158 &, 000 &,- 153 \\
\hline & $\mathrm{P}$ & ,483 &, 044 & ,484 & ,229 & ,999 & ,244 \\
\hline \multirow[t]{2}{*}{ Family } & $\begin{array}{l}\text { Spear } \\
\text { man r- } \\
\text { test }\end{array}$ &,- 169 &,- 121 &, $376^{* *}$ &,- 215 &,- 242 &, $416^{* *}$ \\
\hline & $\mathrm{P}$ &, 196 &, 356 &, 003 &, 098 &, 062 &, 001 \\
\hline
\end{tabular}

Based on the data obtained, we can say that there are significant correlations between: existential meaning and existential poster (negative relationship); hedonistic meaning and status, cognitive and family posters; sense of self-realization and communicative, hedonistic, existential and family posters; status meaning and status poster (negative relationship); family meaning and cognitive and family posters (negative relationship). 


\section{Discussions}

Generalization of the results suggests that the number of leaders in the estimates goes poster "self-Realization", which in all groups receives the highest scores. Then, according to the degree of demand there is a "Cognitive" poster, the evaluation of which in all selected groups occupies the second and third positions. The "Family" poster is also highly rated in three groups of seven. The lowest marks in four groups get a "Communicative" poster, in three groups-an "Existential" poster. The presented results, on the one hand, reflect the General psychological characteristics of adolescence, with a characteristic focus on self-determination and self-realization, the desire to navigate and learn about the world (which corresponds to the social status of the student), as well as their focus on the implementation of family values, family creation and related love and emotionality [17].

At the same time, the analysis of tabular data allows to notice the following. "Communication" poster is above all appreciated by the students "Communicative aspects", below all the respondents belonging to the group "Status meanings". Representatives of the group "Existential meanings", followed by the Respondent group "family meanings", put "Family" the poster of the highest score; the respondents of the group "Sense of fulfillment" appreciate "Family" poster below.

Thus, it can be concluded that in advertising there is a translation of the corresponding meanings in accordance with the dominant life meanings and semantic settings of students.

When analyzing the results of the study, it is necessary to consider that the methodology Kotlyakov, V. Y. built on a ranking of the senses [15], which means: the smaller rank will be given to the Respondent in answering the questions, the higher valued category of meaning in the system of life expectations of a person. This clarification is important for understanding and interpreting the correlation results.

Correlation analysis shows that there is a relationship between respondents 'life meanings and respondents' evaluation of advertising posters. The table presents

results that show that the more existential meaning is expressed, the lower the "Existential" poster is rated. According to Kotlyakov's method, this means that the dominance of existential meanings in the system of life meanings (mathematically low values) leads to high estimates of the "Existential" poster.

The dominance of status meanings in the system of life meanings (mathematically low values) leads to high ratings of the "Status" poster. The dominance of family meanings in the system of life meanings (mathematically low values) leads to high scores of "Cognitive" and "Family" posters.

Low representation of hedonistic meanings (mathematically high values) has direct links with the evaluation of "Status", "Cognitive" and "Family" posters. The intensity of the meaning of self-realization leads to high scores of "Communicative", "Hedonistic", "Existential" and "Family" posters.

The results suggest that the use of psychological techniques in advertising, focused on the" adjustment of values", leads to the translation of the corresponding meanings represented in the image, visual images, and actualizes the corresponding semantic installation for the implementation of this meaning. The results show that in most cases, students with the dominance of the relevant values higher estimate those advertising posters in which this vital value and meaning is presented, depicted in the form of an image. As psychological mechanisms we can talk about the mechanism of identification with this poster and this value, projected by the authors of advertising in the image. The study correlated with the results of the research presented in the works of O. E. Vanin, G. S. Alalykina [18] V. P. Sanova [11], S. V. Elias [13], which emphasize the dependence of the efficiency of advertising impact from the accounting value and meaning attitudes of consumers. 
The study also shows that the broadcast of advertising meanings is carried out through the channel of correspondence to the value and semantic features of respondents. The principle of correspondence is developed in the theory of psychological systems V. E. Klochko, thereby justifying the selectivity of perception and interaction of man with the world [19]. In the continuation of the implementation of this principle, we can say that for the successful perception of advertising, and therefore for its effective implementation, a consonance in the translation of meanings is necessary, their correspondence between the broadcast and the formed meanings of consumers.

Thus, based on the results of the study, we can assume that when students perceive advertising of different semantic orientation, semantic installations will have a certain value.

\section{Conclusion}

Summing up the results of the study, we can conclude the following. The perception and translation of the meanings presented in advertising posters is largely determined by the peculiarities of the semantic sphere of students and their actual semantic settings.

Based on the study, students were assigned to different groups depending on the dominant meanings in the system of life meanings: "family", "self-Realization", "Hedonistic", "Altruistic", "Existential", "Status", "Communicative".

It was shown that there are pronounced differences in the perception and evaluation of advertising posters by students assigned to different semantic groups.

It was also revealed that there is a relationship between the life meanings of students and the evaluation of advertising posters.

\section{References}

1. L.F. Alwitt, A.A. Mitchell, Psychological processes and advertising effects (NJ:

Lawrence Erlbaum Associates, Publishers, Hillsdale, 1985)

2. Izian Idris, Mohd Shukri Ab Yajid and Ali Khatibi. Journal of Social Sciences, 5(2), 104111, (2009)

3. A. Inkeles, A. R. Pratkanis, S. J. Breckler, A. G. Greenwald, Attitude structure and function (NJ.: Lawrence Erlbaum Associates, 1989)

4. W. Wells, S. Moriarty, J. Burnett, Advertising: Principles and Practice. (Peter, St. Petersburg, 2008)

5. A.G. Asmolov, Beyond Consciousness: Methodological Problems of Non-Classical Psychology (Sense, Moscow, 2002)

6. D.A. Leontyev, Psychology of meaning: nature, structure and dynamics of semantic reality (Sense, Moscow, 2003)

7. I.V. Abakumova, L.Ts. Kagermazova, P.N. Ermakov, Technologies of directional translation of meanings in the practice of the educational process (Credo, Moscow, 2016)

8. A.K. Belousova, Educational Psychology, 9, 4-14, (2015)

9. E.A. Suroedova, Psychology of Education, 1, 4-17, (2015)

10. F. Kotler, Fundamentals of Marketing, (Williams, Moscow, 2012)

11. V.P. Shaneov, Hidden human control. The Psychology of Manipulation (Publishing House AST, Moscow:, 2001)

12. J. Trout, E. Rice, Positioning. The battle for recognition (Peter, St. Petersburg, 2004)

13.S. Ilyinsky, Public Relations, Advertising, Marketing, Neurolinguistic Programming,

(AST, East-West, Moscow, 2006) 
14.O.S. Posypanova, Economic Psychology: Psychological Aspects of Consumer Behavior (KSU named after KE Tsiolkovsky, Kaluga, 2012)

15. V.Yu. Kotlyakov, Siberian Psychology Today, 2, 18-21, (2003)

16. A.N. Lebedev, O.V. Gordyakova, Psychological Impact: Mechanisms, Strategies, Opportunities for Counteraction, 129-141 (Institute of Psychology RAS, Moscow, 2012)

17. I.V. Shapovalenko, Age Psychology, (Academy, Moscow, 2004)

18. O.E. Vanina, G.S. Alalykina, Theory and Practice of Social Development, 11, 121-124, (2013)

19. V.E. Klochko, Self-organization in psychological systems: problems of the formation of the mental space of an individual (an introduction to transpersive analysis) (Tomsk, 2005) 